\title{
Production of multiple cytokines and induction of cachexia in athymic nude mice by a new anaplastic thyroid carcinoma cell line
}

\author{
J W-C Chang ${ }^{1}$, K-Y Yeh ${ }^{1}$, Y-C Shen ${ }^{1,2}$, J-J Hsieh ${ }^{1}$, C-K Chuang ${ }^{3,4}$, \\ S-K Liao ${ }^{4}$, L-H Tsai $^{5}$ and C-H Wang ${ }^{1,2}$ \\ ${ }^{1}$ Department of Hematology/Oncology, Chang Gung Memorial Hospital, Taoyuan 333, Taiwan \\ ${ }^{2}$ Department of Internal Medicine, Chang Gung Memorial Hospital, Keelung 204, Taiwan \\ ${ }^{3}$ Department of Urology, Chang Gung Memorial Hospital, Taoyuan 333, Taiwan \\ ${ }^{4}$ Graduate Institute of Clinical Medicine, Chang Gung University, Taoyuan 333, Taiwan \\ ${ }^{5}$ Research Division, Show Chwun Memorial Hospital, Changhua 500, Taiwan \\ (Requests for offprints should be addressed to C-H Wang, Department of Internal Medicine, Chang Gung Memorial Hospital, 222 Mai Chin Road, Keelung \\ 204, Taiwan; Email: chwang@adm.cgmh.org.tw)
}

\begin{abstract}
An anaplastic thyroid cancer cell line, Thena, was recently established in our laboratory following radical thyroidectomy of a patient with anaplastic thyroid cancer. Microscopically, Thena cells were spindle-shaped or small round cells. Thena cells were reactive with cytokeratin AE1/ AE3 antibodies, epithelial membrane antigen, interleukin (IL)-6, epithelial growth factor receptor, transforming growth factor (TGF)- $\alpha$, vascular endothelial growth factor, and vimentin. Thena cells secreted high levels of IL-6, leukemia inhibitor factor (LIF), tumor necrosis factor (TNF) $-\alpha$, and TGF- $\beta 1$ in the culture supernatants, as
\end{abstract}

determined by enzyme-linked immunosorbent assay. When subcutaneously injected with Thena cells, athymic nude mice developed tumor masses in the skin within 2 weeks. Furthermore, Thena cells induced cachexia in these tumor-bearing mice. High levels of human IL-6, LIF and TGF- $\beta 1$ were detected in the mouse sera. To our knowledge, the Thena cell line is the first thyroid cancer cell line reported to induce cachexia in nude mice. This cachectic animal model is worthy of further study to explore the treatment of thyroid cancer-induced cachexia. Journal of Endocrinology (2003) 179, 387-394

\section{Introduction}

Anaplastic thyroid carcinoma (ATC) is one of the most aggressive neoplasms in humans. The median survival is less than 1 year after initial diagnosis. It commonly occurs in the elderly. Patients suffering from ATC often have a long history of goiter. Dysphagia, dysphonia, respiratory tract compression and cervical pain are the most common complaints of ATC patients. The common presence of admixed foci of differentiated thyroid cancer in ATC suggests that it arises through the mechanism of 'dedifferentiation'. The expression of keratin by immunohistochemical staining further supports this argument (see Lampertico 1993 for review). Multimodality treatment combining chemotherapy, radiotherapy and surgery for patients with anaplastic carcinoma have not been efficient in terms of disease-free and overall survival. The disease also causes cachexia and airway compression, resulting in patient morbidity and mortality. Therefore, a better understanding of the tumor biology of ATC may lead to novel treatment of this devastating disease.

Several growth factors were reported to stimulate growth of normal thyroid epithelial cells. De-regulation of these factors and/or their receptors may lead to the growth of thyroid tumors. Cultured normal thyroid follicular cells constitutively produce high levels of interleukin (IL)-6 and IL-8 (Weetman et al. 1992). Reduced IL-6 expression has been demonstrated in anaplastic thyroid carcinomas (Basolo et al. 1998). Over-expression of transforming growth factor- $\alpha$ (TGF- $\alpha$ ) has been implicated in thyroid tumors. By binding to its receptor, epidermal growth factor receptor (EGFR), TGF- $\alpha$ acted to stimulate tumor growth by an autocrine mechanism (Haugen et al. 1993). Aberrant activation of EGFR leading to activation of the Met gene has also been indicated in association with the malignant phenotype of anaplastic thyroid carcinomas (Bergstrom et al. 2000). Transforming growth factor- $\beta$ (TGF- $\beta$ ) inhibits the growth of most epithelial cells including cancer cells. Irresponsible to negative regulation by TGF- $\beta$ has been implicated in the progression of epithelial tumors (Blaydes \& Wynford-Thomas 1996). Loss of TGF- $\beta$ type II receptor has also been demonstrated to contribute to the progression of well-differentiated thyroid carcinomas toward undifferentiated anaplastic ones (Lazzereschi et al. 1997).

Cultured cells and cell lines provide a useful means to study the molecular event and regulatory mechanism of 
cell growth and also the neoplastic progression of this type of cancer. Recently, we established a new thyroid carcinoma cell line, Thena, following thyroidectomy of a patient with anaplastic thyroid carcinoma. In this report, we analyze the morphological features, immunophenotypic characteristics, and cytokine production of this cell line. A cachectic model has also been established in nude mice bearing Thena cells. To our knowledge, Thena is the first thyroid carcinoma cell line reported to induce cachexia in athymic nude mice. Further studies using Thena cells to explore the mechanisms and treatment in cancer-induced cachexia are warranted.

\section{Materials and Methods}

\section{Patient}

A 75-year-old woman presented with a thyroid mass and was admitted to Chang Gung Memorial Hospital. She had had the mass for more than 10 years. The mass had enlarged rapidly in the 6 months before admission to the hospital, leading to neck pain, erythema, and airway compression. Poor appetite and body weight loss was also noted. Palliative resection of the tumor to relieve symptoms was performed. The tissue was frozen in liquid nitrogen or fixed in formalin for histopathological diagnosis and immunohistochemical staining. Part of the specimen was transferred to our laboratory in complete medium for subsequent processing.

\section{Cell line establishment and culture conditions}

The thyroid tumor specimen, obtained by thyroidectomy with the prior informed consent of the patient, was minced mechanically with a pair of scissors. Single cells were seeded into a T-25 flask (Nunc, Naperville, IL, USA) in RPMI 1640 medium (Life Technologies, Gaithersburg, MD, USA) supplemented with $10 \%$ fetal bovine serum (FBS; HyClone, Logan, UT, USA), 1\% L-glutamine, 1\% sodium pyruvate, $100 \mathrm{U} / \mathrm{ml}$ penicillin, and $50 \mu \mathrm{g} / \mathrm{ml}$ streptomycin (Life Technologies). Cells were incubated at $37{ }^{\circ} \mathrm{C}$ in an incubator supplied with $5 \%$ humidified $\mathrm{CO}_{2}$. Tumor colonies were observed 1 week after seeding, surrounded by fibroblasts. Occasionally, fibroblasts were depleted by light trypsin-EDTA $(0 \cdot 02 \%$, Life Technologies). Intermittently, cells were resuspended in complete medium containing 10\% dimethyl sulfoxide (DMSO; Sigma, St Louis, MO, USA) and frozen in liquid nitrogen for further use. Four thyroid carcinoma cell lines, ARO, CGTH-w1, SW579 and WRO were maintained in RPMI complete medium as described above. ARO, SW579, WRO (all from the American Type Culture Collection, Rockville, MD, USA) and CGTH-w1 (Lin et al. 1998) cells were kindly provided by Dr Jen-Der Lin, Department of Metabolism, Chang Gung Memorial
Hospital. ARO is an anaplastic thyroid carcinoma cell line and SW579 is a poorly differentiated papillary thyroid carcinoma cell line; CGTH-w1 and WRO are follicular thyroid carcinoma cell lines.

\section{Morphological analysis by electron microscopy}

Cells grown in 3-cm dishes were fixed with $2.5 \%$ glutaraldehyde in phosphate-buffered saline (PBS) for $2 \mathrm{~h}$ at $4{ }^{\circ} \mathrm{C}$. After being washed with PBS, cells were post-fixed with $1 \%$ osmium tetroxide in $0.1 \mathrm{~mol} / 1$ cacadylate buffer and embedded in epoxy resin (Nacalai Tesque, Kyoto, Japan). They were cut into thin sections with a Reichert ultracutter (Leica, Germany), stained with uranyl acetate and lead citrate (Electron Microscopy Sciences, Fort Washington, PA, USA) and examined with an H-7500 electron microscope (Hitachi, Tokyo, Japan).

\section{In vitro cell growth}

Cells were seeded into wells of 6-well plates (Nunc) at $2 \times 10^{5}$ cells/well in $2 \mathrm{ml}$ complete RPMI medium. Triplicate wells were trypsinized every other day. Cell numbers were counted using the Trypan Blue exclusion method. Culture supernatants were collected and frozen at $-80{ }^{\circ} \mathrm{C}$ for the cytokine production assay. The population doubling time was estimated at the $\log$ phase of the growth curve.

\section{Immunohistochemical staining}

Cells were seeded into wells of Lab-Tek chamber slides (Nunc) at $5 \times 10^{4}$ cells per well and incubated for $24 \mathrm{~h}$. Immunohistochemical staining was performed according to the manufacturer's instructions (Vector, Burlingame, CA, USA). In brief, cells were fixed with glacial acetone and air-dried. The following antibodies, AE1/AE3 (Signet, Dedham, MA, USA), carcinoembryonic antigen (CEA; Novacastra, Newcastle, UK), cytokeratin (CK) -7, $-8,-18,-19$, and -20 (all from Dako, Glostrup, Denmark), CD40 (BD Pharmingen, San Jose, CA, USA), CD44 (Bender MedSystems, Vienna, Austria), desmin (Dako), E-cadherin (Biodesign, Saco, ME, USA), EGFR (Santa Cruz Biotechnology Inc., Santa Cruz, CA, USA), epithelial membrane antigen (EMA; Dako), human chorionic gonadotropin ( $\beta$-hCG; Signet), intracellular adhesion molecule (ICAM-1; Dako), proliferating cell nuclear antigen (PCNA; Dako), TGF- $\alpha$ (Santa Cruz), thyroglobulin (Dako) thyroid-stimulating hormone receptor (TSH-R; Santa Cruz) and vascular endothelial growth factor (VEGF) (BD Pharmingen), were added and incubated for $1 \mathrm{~h}$ after blocking the wells with 1:5000 diluted normal horse serum. Anti-HLA-ABC antibody (W6/32, Dako) and normal mouse serum served as the positive and negative controls respectively. After three washes, the appropriate biotin-conjugated secondary antibodies were 
added and further incubated for $1 \mathrm{~h}$. An avidin-biotin complex (ABC Elite, Vector) was applied followed by the addition of 3-amino-9-ethylcarbazole (AEC; Sigma) to achieve a permanent color change in the reactive cells. Cells were counterstained with hematoxylin (Gill's formula \#3, Electron Microscopy Sciences).

\section{Cytokine production}

Levels of cytokines secreted by Thena cells in in vitro culture, including IL-6, IL-10, leukemia inhibitor factor (LIF), TGF- $\alpha$, TGF- $\beta 1$, and tumor necrosis factor- $\alpha$ (TNF- $\alpha$ ), were determined by an enzyme-linked immunosorbent assay (ELISA) method, following the instructions of the manufacturer. All the assay kits were from R\&D Systems (Minneapolis, MN, USA) except for TGF- $\alpha$, which was from Oncogene (Boston, MA, USA). The sensitivities of these assay kits were as follows: IL-6, $0 \cdot 2 \mathrm{pg} / \mathrm{ml}$; LIF, $8 \mathrm{pg} / \mathrm{ml}$; TGF- $\alpha, 2.1 \mathrm{pg} / \mathrm{ml}$; TGF- $\beta 1$, $7 \mathrm{pg} / \mathrm{ml}$; and TNF- $\alpha, 4 \cdot 4 \mathrm{pg} / \mathrm{ml}$. In brief, culture supernatants collected from $72-\mathrm{h}$ cultures were added to a 96-well plate pre-coated with anti-cytokine antibodies and incubated for $2 \mathrm{~h}$. After washing three times with wash buffer, horseradish peroxidase-conjugated secondary antibody was added and further incubated for $2 \mathrm{~h}$. A chromogen (tetramethylbenzidine and hydrogen peroxide mixed at 1:1) was then added for color formation. The reaction was stopped by the addition of $1 \mathrm{M} \mathrm{H}_{2} \mathrm{SO}_{4}$. Results were read with a Dynatech MR5000 ELISA reader (ThermoLabsystems, Chantilly, VA, USA) at $450 \mathrm{~nm}$ with correction at $570 \mathrm{~nm}$.

\section{Xenotransplantation and tumor cachectic model in nude mice}

Nude mice (Balb/c nu/nu) were purchased from the Animal Facility of the National Science Counsel (NSC), Taiwan. They were housed in an isolated pathogen-free cage and were fed with UV-sterilized pellets and autoclaved distilled water. Thena cells were harvested by trypsinization and were washed twice with PBS. Mice were subcutaneously injected with $5 \times 10^{6}$ Thena cells resuspended in $0.1 \mathrm{ml}$ PBS at the right hind leg. Tumor growth was monitored every other day and the sizes of tumors were measured with a caliper. Body weight was measured using a digital scale once a week after mice had been anesthetized with ketamine $(5 \mathrm{mg} / \mathrm{kg}$ ). All procedures used in this animal study were performed in accordance with institutional guidelines for animal care at Chang Gung Memorial Hospital.

\section{Statistical analysis}

All values are expressed as the mean \pm S.E. Student's $t$-test was used to compare the differences in all categories. $P$ values less than 0.05 were considered statistically significant.
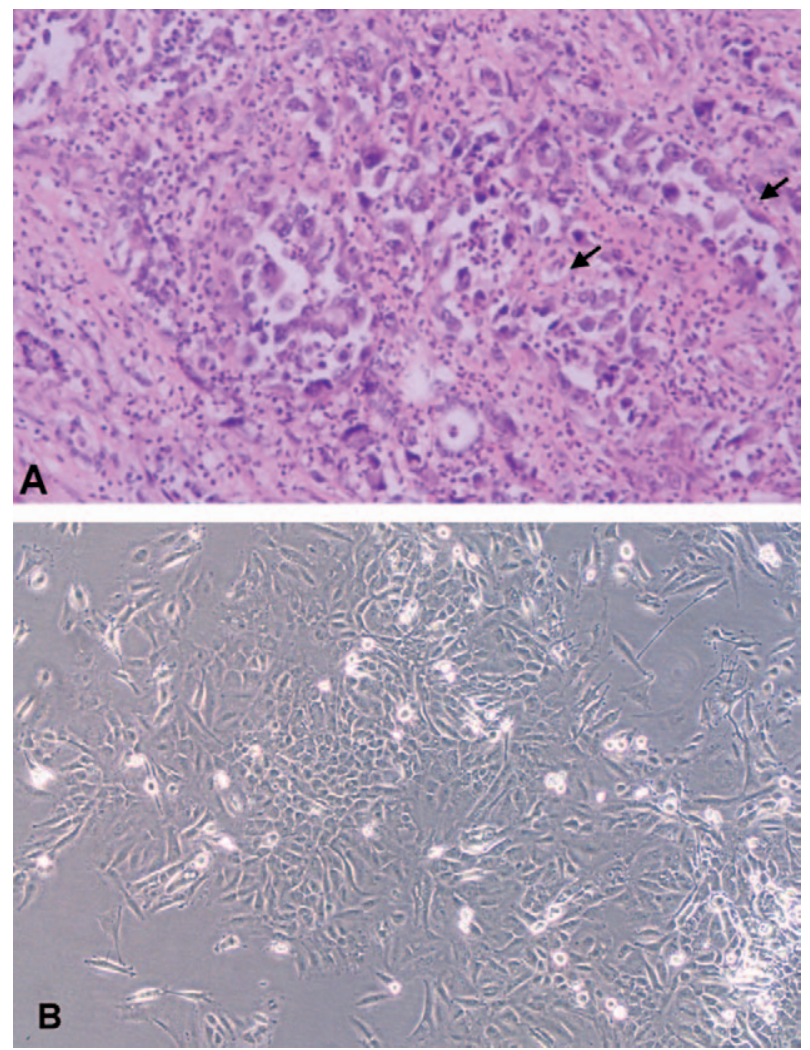

Figure 1 (A) Hematoxylin and eosin staining of primary tumor specimen. The tumor mass was composed of some papillary tumor cells (arrows) with a majority of anaplastic components. (B) Phase contrast microphotograph of Thena cells in vitro. Thena cells displayed polygonal or spindle-shaped epithelial cell morphology. Osteoclast-like giant cells were occasionally seen in early culture. However, they were eliminated following several passages (original magnification, $\times 100$ ).

\section{Results}

Isolation and characterization of Thena cells

Hematoxylin and eosin (H\&E) staining showed that the tumor mass was composed of some well-differentiated papillary cancer cells, with a majority of anaplastic cancer cells (Fig. 1A). Intensive infiltration of granulocytes was observed. Extensive necrosis and areas of trabecular pattern were seen. Numerous osteoclast-like giant cells were also observed. Immunohistochemical staining of the primary tumor was strongly positive for cytokeratin AE1/ AE3, but negative for leukocyte common antigen (LCA); thyroglobulin was negatively stained (data not shown).

Single cells obtained by mincing the tumor specimen mechanically were seeded into a T-25 flask in RPMI complete medium. Following the observation of tumor colonies, contaminated fibroblasts were depleted by light trypsinization $(0 \cdot 02 \%)$. After five passages, pure cancer cells were obtained. This anaplastic thyroid carcinoma cell 

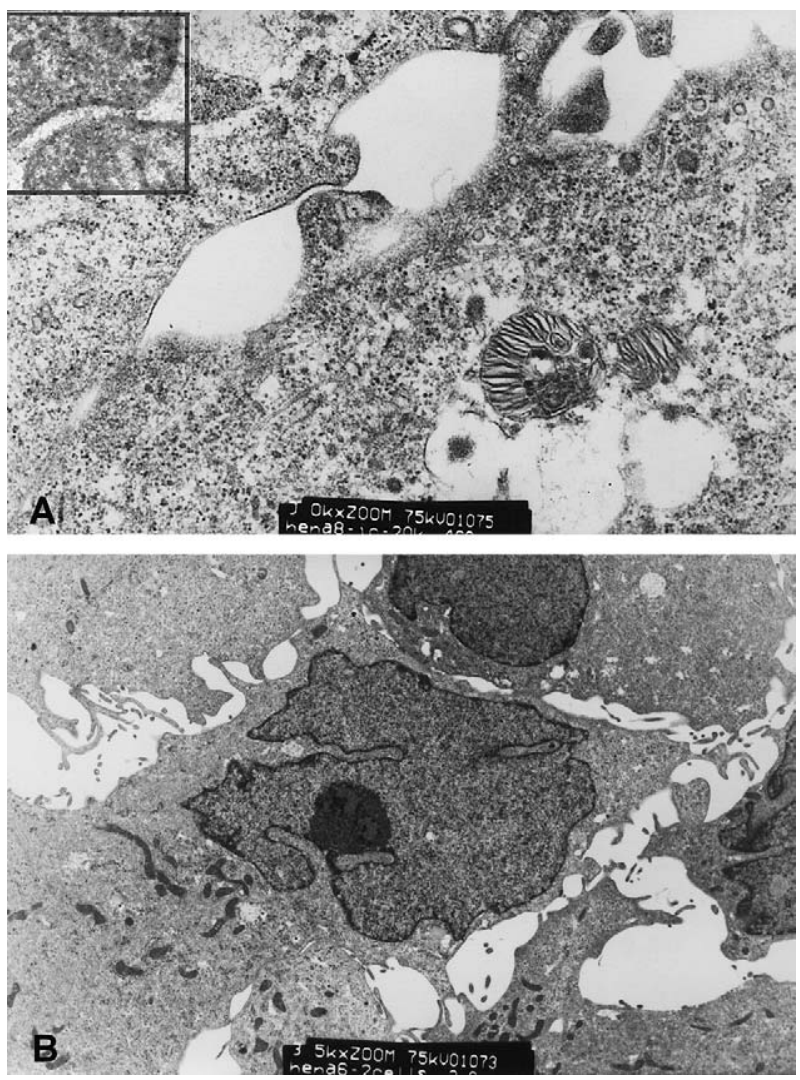

Figure 2 Electron microphotograph of Thena cells. (A) Abundant electron-dense material (inset, $\times 50000$ ) was found along the intercellular junction (original magnification, $\times 3$ 500). (B) Plenty of microvilli and mitochondria, well-developed endoplasmic reticulum, and cytoplasmic invagination were observed (original magnification, $\times 20000$ )

line was named Thena. Morphologically, Thena cells showed a polygonal or spindle-shaped epithelial cell morphology under phase contrast microscopy and the nucleus to cytoplasm ratio was large, as illustrated in Fig. 1B. Thena cells firmly attached to the bottom of the flask. A longer period of trypsinization was required ( $>5 \mathrm{~min}$ ) to harvest the cells. Thena cells were maintained in vitro for more than 40 passages. The population doubling time was $29 \cdot 7 \mathrm{~h}$.

Electron microscopic study revealed well-developed endoplasmic reticulum, numerous mitochondria, and cytoplasmic invagination in Thena cells. Plenty of microvilli were observed on the luminal surface of the tumor cells (Fig. 2B). Electron-dense materials were found along the cell membrane of the intercellular junction (Fig. 2A and insert). These morphological characteristics of Thena cells are similar to those of undifferentiated thyroid carcinoma cells.

Immunohistochemical staining showed that Thena cells were positively reactive to antibodies against AE1/AE3, CK-7, CK-8, CK-18, CD40, CD44, EGFR, EMA,
$\beta$-hCG, ICAM-1, PCNA, TGF- $\alpha$ and VEGF, but stained negatively with antibodies to CEA, CK-19, CK-20, desmin, E-cadherin, thyroglobulin and TSH-R. Some staining patterns are illustrated in Fig. 3.

\section{Cytokine production}

Culture supernatants of Thena were tested for the release of IL-6, IL-10, LIF, TGF- $\alpha$, TGF- $\beta 1$, and TNF- $\alpha$. Three independent experiments were performed. A set of representative data is depicted in Table 1. LIF and TNF- $\alpha$ were only detected in Thena cells. TNF- $\alpha$ secretion reached $\mathrm{ng} / \mathrm{ml}$ concentrations. Both $\mathrm{ARO}$ and Thena cells released mild amounts of TGF- $\alpha$ into the culture supernatants. The production of IL-6 by Thena cells was extremely high, with 20 -fold more than that of other cell lines tested. All cell lines secreted TGF- $\beta 1$. Cytokine secretion by ARO cells was the lowest among these cell lines, with the exception of TGF- $\alpha$. IL-10 was not detected in any of the cell lines.

\section{Induction of cachexia in nude mice}

Tumor growth $(>3 \times 3 \mathrm{~mm})$ was observed within 2 weeks (10-14 days) in nude mice injected subcutaneously with Thena cells. Rapid tumor growth was seen in the first month, followed by a slow growth. Cachexia syndrome was observed in 4 of 4 Thena-injected mice 4 weeks after the inoculation. Weight loss proceeded after tumor growth reaching plateau. Mice were killed 1 month after the observation of cachexia syndrome (Fig. 4A). At this point, the average of the largest diameter of tumors was $13.8 \mathrm{~mm}$ $(12-15 \mathrm{~mm})$; however, the average body weight of the mice had decreased by $23 \%$ compared with that of agematched controls $(21.75 \mathrm{~g} \pm 1.69 \mathrm{~g}, n=4$ vs $28.28 \mathrm{~g} \pm$ $0 \cdot 86 \mathrm{~g}, \quad n=3, \quad P<0 \cdot 01)$. High levels of human IL-6 $(502 \cdot 4 \pm 82 \cdot 5 \mathrm{pg} / \mathrm{ml}), \quad$ LIF $(764.5 \pm 138 \cdot 7 \mathrm{pg} / \mathrm{ml})$ and TGF- $\beta 1(82 \cdot 7 \pm 12 \cdot 4 \mathrm{ng} / \mathrm{ml})$ were detected in the serum of the cachectic mice. H\&E staining of tumor sections revealed the appearance of anaplastic thyroid cancer cells (Fig. 4B). Cells derived from nude mouse xenografts (Thena-Nu) secreted even higher levels of cytokines than their parental counterparts, except for TGF- $\beta 1$ (Table 1) $(P>0.05$ for TGF- $\beta 1 ; P<0.05$ for TGF- $\alpha ; P<0.01$ for IL-6, LIF, and TNF- $\alpha$ ).

\section{Discussion}

We established an anaplastic thyroid carcinoma cell line, Thena. Thena cells produced high levels of growth factors in culture supernatants, including IL-6, LIF, TGF- $\beta 1$, and TNF- $\alpha$ (Table 1$)$. Thena cells exhibited a very aggressive growth in nude mice, accompanied by the induction of cancer cachexia (Fig. 4A). Small tumor burden indicated soluble factors secreted by Thena cells might contribute to 

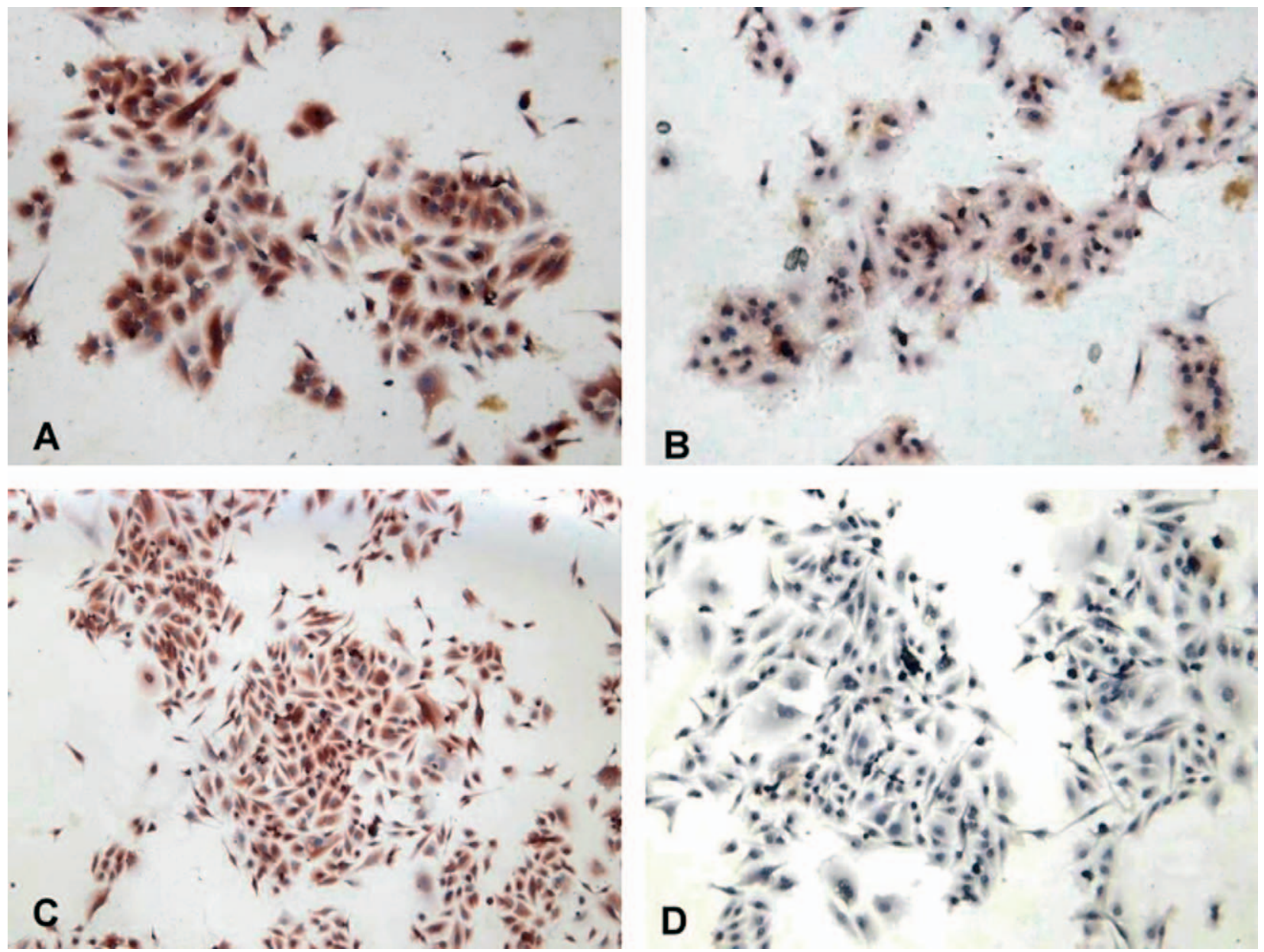

Figure 3 Immunohistochemical staining of Thena cells. Thena cells were positively reactive with antibodies against (A) AE1/AE3, (B) EGFR, and (C) ICAM-1 but were negatively stained with antibody to thyroglobulin (D) (original magnification, $\times 100$ ).

this paraneoplastic syndrome. High levels of IL-6, LIF and TGF- $\beta 1$ were detected in the serum of these cachectic mice, indicating that these three cytokines might play an important role in the induction of cachexia in this mouse model.
The expression of cytokines in the development and progression of human epithelial tumors is only partially defined. In thyroid carcinoma, the existence of an inverse relationship between IL-6 production and tumor aggressiveness was demonstrated (Basolo et al. 1998).

Table 1 Production of soluble growth factors by thyroid carcinoma cell lines. Supernatants were collected from 72-h cultures. Results for IL-6, TGF- $\beta 1$, LIF, and TNF- $\alpha$ are expressed as ng/ $10^{6}$ cells; results for TGF- $\alpha$ are expressed as $\mathrm{pg} / 10^{6}$ cells. Experiments were performed in triplicate

Cell line

\begin{tabular}{|c|c|c|c|c|c|c|}
\hline & ARO & SW579 & CGTH-w1 & WRO & Thena & Thena-Nu* \\
\hline IL-6 & $<0 \cdot 1$ & $5 \cdot 28 \pm 0 \cdot 32$ & $2 \cdot 32 \pm 0 \cdot 21$ & $4 \cdot 61 \pm 0.51$ & $110 \cdot 53 \pm 3 \cdot 62$ & $>160$ \\
\hline TGF- $\beta 1$ & $2 \cdot 00 \pm 0 \cdot 21$ & $4 \cdot 91 \pm 0 \cdot 63$ & $3 \cdot 43 \pm 0 \cdot 32$ & $1 \cdot 21 \pm 0 \cdot 12$ & $8 \cdot 12 \pm 1 \cdot 20$ & $6 \cdot 73 \pm 0.92$ \\
\hline LIF & UD & UD & UD & UD & $0.71 \pm 0.06$ & $2 \cdot 68 \pm 0 \cdot 19$ \\
\hline TGF- $\alpha$ & $99 \cdot 0 \pm 10 \cdot 5$ & UD & UD & UD & $115 \cdot 7 \pm 10 \cdot 2$ & $162 \cdot 3 \pm 15 \cdot 3$ \\
\hline TNF- $\alpha$ & UD & UD & UD & UD & $1 \cdot 06 \pm 0 \cdot 10$ & $1 \cdot 82 \pm 0 \cdot 21$ \\
\hline
\end{tabular}

${ }^{*}$ Cells derived from nude mouse xenografts.

UD, undetectable, below the minimum detection limit of the kit. 

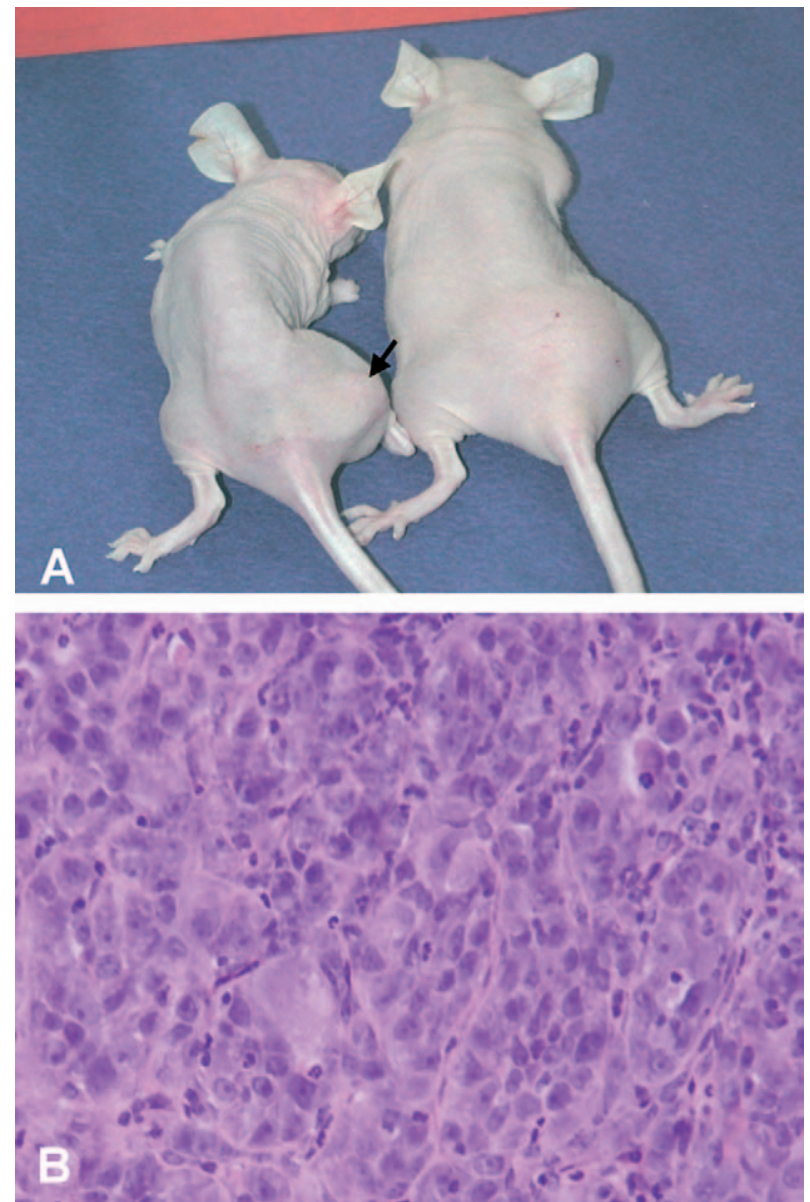

Figure 4 (A) Induction of cachexia by Thena cells. Athymic nude mice were injected s.c. with Thena cells at $5 \times 10^{6}$ in $0 \cdot 1 \mathrm{ml}$ PBS. Tumor growth was observed 10 days after the injection (arrow). Four weeks later, mice started to lose weight. This photo was taken 8 weeks after tumor inoculation. A normal age-matched mouse was included for comparison. (B) Histochemical staining of a tumor section revealed the typical morphology of undifferentiated tumor cells (original magnification, $\times 200$ ).

Nonetheless, our results did not correlate with such observations. Thena cells secreted an extraordinarily high level of IL-6 in the culture supernatants, whereas the follicular thyroid cancer cell lines CGTH-w1 and WRO secreted much lower levels of IL-6 (Table 1). Additionally, cells derived from the nude mouse xenograft (Thena-Nu), which were interpreted as fully anaplastic thyroid carcinoma cells histochemically, secreted an even higher amount of IL-6 (>160 ng/10 cells) than that of their parental cells. The discrepancies between these studies may be due to the different cell lines employed. For example, the poorly differentiated papillary thyroid carcinoma cell line, SW579, produced higher IL-6 than CGTH-w1, a well-differentiated follicular thyroid carcinoma cell line $(P<0 \cdot 01)$.
TGF- $\alpha$ is not expressed in normal thyroid tissues. Increased TGF- $\alpha$ expression has been associated with malignant transformation of thyroid cells (Haugen et al. 1993). TGF- $\alpha$ was detected in Thena cells. Cells were also stained positively with antibody to EGFR in the membrane and cytoplasm (Fig. 3B). Cells derived from nude mouse xenografts secreted an even higher level of TGF- $\alpha$ in the culture supernatants $\left(162 \cdot 3 \pm 15 \cdot 3 \mathrm{pg} / 10^{6}\right.$ cells vs $115 \cdot 7 \pm 10 \cdot 2 \mathrm{pg} / 10^{6}$ cells, $\left.P<0 \cdot 05\right)$ and exhibited a shorter population doubling time $(26.8 \mathrm{~h}$ vs $29 \cdot 7 \mathrm{~h}) \mathrm{com}-$ pared with that of their parental cells. These results indicate that the TGF- $\alpha$ /EGFR autocrine loop is in operation in Thena cells and this autocrine mechanism may result in the progression of the disease (Nilsson et al. 1995).

Thena cells exhibited a short lag phase, with rapid tumor growth in nude mice as compared with other well-differentiated thyroid carcinoma cell lines described in the literature. Thena cells produced measurable tumors in nude mice ( $>3 \mathrm{~mm}$ in diameter) within 2 weeks, whereas WRO, a follicular thyroid carcinoma cell line, produced tumors 4 months after the injection (Estour et al. 1989). B-CPAP, a papillary thyroid carcinoma cell line, developed tumors of $0.5 \mathrm{~mm}$ in diameter 8 weeks after the inoculation (Fabien et al. 1994). Direct comparisons between Thena and these cell lines would be more ideal to conclude these results. The in vivo growth of Thena cells was comparable to other established anaplastic thyroid carcinoma cell lines (Dahlman et al. 2002). Nevertheless, none of the published thyroid carcinoma cell lines have been reported to induce cancer cachexia in nude mice.

Cancer-induced cachexia may be due to endogenous or tumor-associated factors. Several cytokines are involved in the process of this paraneoplastic syndrome, such as TNF- $\alpha$ (Yoneda et al. 1991), TGF- $\beta 1$ (Zugmaier et al. 1991), interferon- $\gamma$ (Matthys et al. 1991), IL-1 (Gelin et al. 1991), IL-6 (Tamura et al. 1995) and LIF (Mori et al. 1991). Specific neutralization of these mediators with antibodies in animal models of cachexia confirmed the involvement of these cytokines in cancer cachexia.

IL-6 was reported to reduce adipose lipoprotein lipase activity, leading to the loss of body fat storage in mice (Greenberg et al. 1992). High human IL-6 was detected in the serum of Thena-bearing mice, indicating that IL-6 should be involved in this cachectic animal model. However, the presence of IL- 6 in the serum of mice bearing non-cachexia-inducing tumors (Fujimoto-Ouchi et al. 1995) suggests that other mediators may also participate in the development of cancer cachexia.

LIF was reported to induce cachexia in animal models with human melanoma cell lines (Mori et al. 1991, Iseki et al. 1995). So far, there are only a few anaplastic thyroid carcinoma cell lines that are reported to secrete LIF. For example, KTC-1 cells (Kurebayashi et al. 2000) secreted much lower levels of LIF $\left(152 \pm 14 \mathrm{pg} / 10^{6}\right.$ cells $\left./ 48 \mathrm{~h}\right)$ in the culture supernatants compared with those of Thena 
cells. Although both the seeding number and culture period were different in these two studies, KTC-1 cells did not induce cachexia in the nude mouse. LIF was 100-fold more potent than IL-6 for inhibition of lipoprotein lipase activity (Berg et al. 1994). High human LIF was detected in Thena-bearing cachectic mouse sera, suggesting that LIF could play a more critical role than IL-6 in this model.

Thena cells also secreted high levels of TGF- $\beta 1$ in vitro. It is suggested that the de-regulation of TGF- $\beta 1$ by well-differentiated thyroid carcinoma cells might result in anaplastic changes (Blaydes \& Wynford-Thomas 1996). The involvement of TGF- $\beta 1$ in cachexia was demonstrated by injecting recombinant protein into mice instead of TGF- $\beta 1$-producing tumor cells (Zugmaier et al. 1991). Although high TGF- $\beta 1$ content was detected in the serum of Thena-injected nude mice $(82.7 \mathrm{ng} / \mathrm{ml})$, whether TGF- $\beta 1$ plays a role in this cachectic animal model needs further investigation.

Our data add further support to the suggestion that no single cytokine is responsible for all of the abnormalities contributing to cachexia (Soda et al. 1995). Although TNF- $\alpha$ was not detected in the mouse serum, it should not be excluded from the list of possible cachexia mediators in this animal model, given the existence of high TNF- $\alpha$ levels in the culture supernatants of both Thena and Thena-Nu cells (Table 1). The discrepancy may result from rapid clearance by other proteins in vivo.

The expression of TNF- $\alpha$ has been demonstrated in thyroid tissues and thyroid carcinoma cell lines (Aust et al. 1996); however, it was seldom detected as a soluble factor in thyroid carcinoma cells. Trace amounts of TNF- $\alpha$ $(<5 \mathrm{pg} / \mathrm{ml})$ were detected in only two ATC cell cultures (Aust et al. 1996, Sato et al. 2000). Thena cells might be the first thyroid carcinoma cells reported to produce high TNF- $\alpha$ in vitro.

TNF- $\alpha$ may function as an autocrine factor for Thena cells, endowing their resistance to TNF- $\alpha$ (Takeyama et al. 1991). The biological functions of TNF- $\alpha$ in Thena cells may also involve the upregulation of adhesion molecules (Bassi et al. 1995), which could be reflected in the firm attachment to culture vessels in vitro, and factors associated with metastatic potential (Mauceri et al. 2002), conferring their proliferative advantages. Further efforts to identify the biological functions and the regulation of TNF- $\alpha$ in Thena cells are presently underway.

While the involvement of TNF- $\alpha$ in our model of cancer cachexia is not verified, it may induce this paraneoplastic syndrome by influencing the expression of other mediators. IL-1 $\beta$, although undetectable in the culture supernatants, showed an even greater expression than that of IL-6 by ribonuclease protection assay (data not shown). Since both IL-1 $\beta$ and TNF- $\alpha$ have been shown to upregulate the expression of IL-6 and LIF (Billingsley et al. 1996), they may act indirectly to induce cachexia in our animal model.
In conclusion, we established an anaplastic thyroid carcinoma cell line, Thena. This new cell line may provide a good model to study the interplay of cytokines in the pathogenesis of thyroid cancer and cancer-induced cachexia.

\section{Acknowledgements}

Part of this work was presented at the 93rd Annual Meeting of the American Association of Cancer Research, San Francisco, April 1-5 2002.

The authors thank Dr Jen-Der Lin (Department of Metabolism, Chang Gung Memorial Hospital) for providing thyroid carcinoma cell lines for this study and Dr Ying-Shiung Lee (Department of Cardiology, Chang Gung Memorial Hospital) for performing electron microscopy analysis. Dr Jia-Hau Liu's excellent help in animal studies is also appreciated. There is no conflict of interest or potential conflict of interest in this work.

\section{Funding}

This work is supported in part by Chang Gung Medical Research Funds CMRP-912 and CMRP-1040.

\section{References}

Aust G, Heuer M, Laue S, Lehmann I, Hofmann A, Heldin NE \& Scherbaum WA 1996 Expression of tumor necrosis factor-alpha (TNF-alpha) mRNA and protein in pathological thyroid tissue and carcinoma cell lines. Clinical and Experimental Immunology 105 148-154.

Basolo F, Fiore L, Pollina L, Fontanini G, Conaldi PG \& Toniolo A 1998 Reduced expression of interleukin 6 in undifferentiated thyroid carcinoma: in vitro and in vivo studies. Clinical Cancer Research 4 381-387.

Bassi V, Vitale M, Feliciello A, De Riu S, Rossi G \& Fenzi G 1995 Retinoic acid induces intracellular molecule-1 hyperexpression in human thyroid carcinoma cell lines. Journal of Clinical Endocrinology and Metabolism 80 1129-1135.

Berg M, Fraker DL \& Alexander HR 1994 Characterization of differentiation factor/leukemia inhibitory factor effect on lipoprotein lipase activity and mRNA in 3T3-L1 adipocytes. Cytokine 6 425-432.

Bergstrom JD, Westermark B \& Heldin NE 2000 Epidermal growth factor receptor signaling activates met in human anaplastic thyroid carcinoma cells. Experimental Cell Research 259 293-299.

Billingsley KG, Fraker DL, Strassmann G, Loeser C, Fliot HM \& Alexander HR 1996 Macrophage-derived tumor necrosis factor and tumor-derived leukemia inhibitory factor and interleukin-6: possible cellular mechanisms of cancer cachexia. Annual of Surgical Oncology $329-35$.

Blaydes JP \& Wynford-Thomas D 1996 Loss of responsiveness to transforming growth factor beta (TGFbeta) is tightly linked to tumorigenicity in a model of thyroid tumor progression. International Journal of Cancer 65 525-530.

Dahlman T, Lammerts E, Bergstrom D, Franzen A, Westermark K, Heldin NE \& Rubin K 2002 Collagen type I expression in 
experimental anaplastic thyroid carcinoma: regulation and relevance for tumorigenicity. International Journal of Cancer 98 186-192.

Estour B, Van Herle AJ, Juillard GJF, Totanes YL, Sparkes RS, Giuliano AE \& Klandorf H 1989 Characterization of a human follicular thyroid carcinoma cell line (UCLA RO $82 \mathrm{~W}-1$ ). Virchows Archiv B Cell Pathology 57 167-174.

Fabien N, Fusco A, Santoro M, Barbier Y, Dubois PM \& Paulin C 1994 Description of a human papillary thyroid carcinoma cell line. Cancer 73 2206-2212.

Fujimoto-Ouchi K, Tamura S, Mori K, Tanaka Y \& Ishitsuka H 1995 Establishment and characterization of cachexia-inducing and non-inducing clones of murine colon 26 carcinoma. International Journal of Cancer 61 522-528.

Gelin J, Moldawer LL, Lonnroth C, Sherry B, Chizzonite R \& Lundholm K 1991 Role of endogenous tumor necrosis factor alpha and interleukin 1 for experimental tumor and the development of cancer cachexia. Cancer Research 51 415-421.

Greenberg AS, Nordan RP, McIntosh J, Calvo JC, Scow RO \& Jablons D 1992 Interleukin 6 reduces lipoprotein lipase activity in adipose tissue of mice in vivo and in 3T3-L1 adipocytes: a possible role for interleukin 6 in cancer cachexia. Cancer Research $\mathbf{5 2}$ 4113-4116.

Haugen DR, Akslen LA, Varhaug JE \& Lillehaug JR 1993 Demonstration of a TGF-alpha-EGF-receptor autocrine loop and c-myc protein over-expression in papillary thyroid carcinomas. International Journal of Cancer 55 37-43.

Iseki H, Hajimura N, Ohue C, Tanaka R, Akiyama Y \& Yamaguchi K 1995 Cytokine production in five tumor cell lines with activity to induce cancer cachexia syndrome in nude mice. Japanese Journal of Cancer Research 86 562-567.

Kurebayashi J, Tanaka K, Otsuki T, Moriya T, Kunisue H, Uno M \& Sonoo H 2000 All-trans-retinoic acid modulates expression levels of thyroglobulin and cytokines in a new human poorly differentiated papillary thyroid carcinoma cell line, KTC-1. Journal of Clinical Endocrinology and Metabolism 85 2889-2896.

Lampertico P 1993 Anaplastic (sarcomatoid) carcinoma of the thyroid gland. Seminar in Diagnostic Pathology 10 159-168.

Lazzereschi D, Ranieri A, Mincione G, Taccogna S, Nardi F \& Colletta G 1997 Human malignant thyroid tumors displayed reduced levels of transforming growth factor beta receptor type II messenger RNA and protein. Cancer Research 57 2071-2076.

Lin JD, Chao TC, Weng HF \& Lin KD 1998 The role of cytokines and retinoic acid in the regulation of human thyroid cancer cell growth. Cytokine 10 536-539.

Matthys P, Dijkmans R, Proost P, van Damme J, Hermans H, Sobis H \& Billiau A 1991 Severe cachexia in mice inoculated with interferon- $\gamma$-producing tumor cells. International Journal of Cancer 49 77-82.
Mauceri HJ, Seetharam S, Beckett MA, Lee JY, Gupta VK, Gately S, Stack MS, Brown CK, Swedberg K, Kufe DW \& Weichselbaum PR 2002 Tumor production of angiostatin is enhanced after exposure to TNF-alpha. International Journal of Cancer $\mathbf{9 7}$ 410-415.

Mori M, Yamaguchi K, Honda S, Nagasaki K, Ueda M, Abe O \& Abe K 1991 Cancer cachexia syndrome developed in nude mice bearing melanoma cells producing leukemia inhibitory factor. Cancer Research 51 6656-6659.

Nilsson O, Wangberg B, Kolby L, Schultz GS \& Ahlman H 1995 Expression of transforming growth factor alpha and its receptor in human neuroendocrine tumours. International Journal of Cancer $\mathbf{6 0}$ 645-651.

Sato T, Omura M, Saito J, Hirasawa A, Kakuta Y, Wakabayashi Y \& Nishikawa T 2000 Neutrophilia associated with anaplastic carcinoma of the thyroid: production of macrophage colonystimulating factor (M-CSF) and interleukin-6. Thyroid 10 1113-1118.

Soda K, Kawakami M, Kashii K \& Miyata M 1995 Manifestations of cancer cachexia induced by colon 26 adenocarcinoma are not fully ascribable to interleukin-6. International Journal of Cancer $\mathbf{6 2}$ 332-336.

Takeyama H, Wakamiya N, O'Hara C, Arthur K, Niloff J, Kufe D, Sakarai K \& Spriggs D 1991 Tumor necrosis factor expression by human ovarian carcinoma in vivo. Cancer Research 51 4476-4480.

Tamura S, Fujimoto-Ouchi K, Mori K, Endo M, Matsumoto T, Eda H, Tanaka Y, Ishitsuka H, Tokita H \& Yamaguchi K 1995 Involvement of human interleukin 6 in experimental cachexia induced by a human uterine cervical carcinoma xenograft. Clinical Cancer Research 1 1353-1358.

Weetman AP, Bennett GL \& Wong WL 1992 Thyroid follicular cells produce interleukin-8. Journal of Clinical Endocrinology and Metabolism 75 328-330.

Yoneda T, Alsina MA, Chavez JB, Bonewald L, Nishimura R \& Mundy GR 1991 Evidence that tumor necrosis factor plays a pathogenetic role in the paraneoplastic syndromes of cachexia, hypercalcemia, and leukocytosis in a human tumor in nude mice. Journal of Clinical Investigation 87 977-985.

Zugmaier G, Paik S, Wilding G, Knabbe C, Bano M, Lupu R, Deschauer B, Simpson S, Dickson RB \& Lippman M 1991 Transforming growth factor beta 1 induces cachexia and systemic fibrosis without an antitumor effect in nude mice. Cancer Research 51 3590-3594.

Received in final form 20 August 2003

Accepted 1 September 2003 